\title{
A novel DPP IV-resistant C-terminally extended glucagon analogue exhibits weight-lowering and diabetes-protective effects in high-fat-fed mice mediated through glucagon and GLP-1 receptor activation
}

\author{
Aisling M. Lynch • Nupur Pathak • Varun Pathak • \\ Finbarr P. M. O'Harte • Peter R. Flatt • Nigel Irwin • \\ Victor A. Gault
}

Received: 1 May 2014 / Accepted: 27 May 2014 /Published online: 25 June 2014

(C) Springer-Verlag Berlin Heidelberg 2014

\begin{abstract}
Aims/hypothesis Modification of the structure of glucagon could provide useful compounds for the potential treatment of obesity-related diabetes.

Methods This study evaluated $\mathrm{N}$-acetyl-glucagon, (D$\mathrm{Ser}^{2}$ )glucagon and an analogue of (D-Ser ${ }^{2}$ )glucagon with the addition of nine amino acids from the C-terminal of exendin(1-39), namely (D-Ser ${ }^{2}$ )glucagon-exe.

Results All analogues were resistant to dipeptidyl peptidase IV degradation. N-Acetyl-glucagon lacked acute insulinotropic effects in BRIN BD11 cells, whereas (DSer $^{2}$ )glucagon and (D-Ser ${ }^{2}$ )glucagon-exe evoked significant $(p<0.001)$ insulin release. (D-Ser $\left.{ }^{2}\right)$ glucagon-exe stimulated cAMP production $(p<0.001)$ in glucagon- and GLP-1receptor (GLP-1R)-transfected cells but not in glucosedependent insulinotropic polypeptide-receptor-transfected cells. In normal mice, $N$-acetyl-glucagon and $\left(\mathrm{D}-\mathrm{Ser}^{2}\right)$ glucagon retained glucagon-like effects of increasing $(p<0.001)$ plasma glucose and insulin levels. (D-Ser ${ }^{2}$ glucagon-exe was devoid of hyperglycaemic actions but substantially $(p<0.001)$ increased plasma insulin levels. (D-Ser ${ }^{2}$ )glucagon-exe reduced the glycaemic excursion $(p<0.01)$ and increased the insulin secretory $(p<0.01)$ response following a glucose challenge $12 \mathrm{~h}$ after administration. Studies in GLP-1R knockout mice
\end{abstract}

Electronic supplementary material The online version of this article (doi:10.1007/s00125-014-3296-7) contains peer-reviewed but unedited supplementary material, which is available to authorised users.

A. M. Lynch • N. Pathak · V. Pathak · F. P. M. O'Harte · P. R. Flatt • N. Irwin $(\varangle) \cdot$ V. A. Gault

SAAD Centre for Pharmacy and Diabetes, School of Biomedical

Sciences, University of Ulster, Coleraine,

Northern Ireland BT52 1SA, UK

e-mail: n.irwin@ulster.ac.uk confirmed involvement of the GLP-1R pathway in the biological actions of (D-Ser $\left.{ }^{2}\right)$ glucagon-exe. Twice-daily administration of $\left(\mathrm{D}-\mathrm{Ser}^{2}\right)$ glucagon-exe to high-fat-fed mice for 28 days significantly $(p<0.05$ to $p<0.001)$ reduced body weight, energy intake and non-fasting glucose levels, as well as increasing insulin concentrations. Glucose tolerance and insulin sensitivity were significantly $(p<0.01)$ improved and energy expenditure, $\mathrm{O}_{2}$ consumption and locomotor activity were $(p<0.05$ to $p<0.001)$ augmented. The metabolic benefits were accompanied by increases in pancreatic islet number $(p<0.001)$ and area $(p<0.05)$, as well as beta cell area $(p<0.05)$. Beneficial effects were largely retained for 14 days following cessation of treatment.

Conclusions/interpretation This study emphasises the potential of (D-Ser $\left.{ }^{2}\right)$ glucagon-exe for the treatment of obesity-related diabetes.

Keywords Diabetes · GLP-1 · Glucagon · Glucagon-like peptide-1 - Glucose tolerance $\cdot$ Obesity
Abbreviations
DPP IV Dipeptidyl peptidase IV
GIP Glucose-dependent insulinotropic polypeptide
GIP-R GIP receptor
GLP-1 Glucagon-like peptide-1
GLP-2 Glucagon-like peptide-2
GLP-1R GLP-1 receptor
GLP-2R GLP-2 receptor
Glucagon-R Glucagon receptor
OXM Oxyntomodulin
PC Prohormone convertase
RER Respiratory exchange ratio
RP-HPLC Reverse-phase HPLC 


\section{Introduction}

The proglucagon gene is the source of a family of peptides that play an important role in the function of the gut and regulation of insulin secretion, glucose homeostasis and energy balance [1]. Secretion of proglucagon peptides was originally considered to be confined to pancreatic alpha cells and gut L-cells [2]; however, more recent studies suggest that the brain also actively secretes proglucagon-derived peptides [3]. A single gene encodes proglucagon in mammalian species and identical mRNAs are produced in the pancreas and the intestine [4]. Thus, differences in the proglucagon products in these tissues are due to tissue-specific, post-translational processing [5]. In this regard, the action of prohormone convertase (PC) 2 results in formation of glucagon, whereas PC 1/3 activity yields glucagon-like peptide-1 (GLP-1), glucagon-like peptide-2 (GLP-2) and oxyntomodulin (OXM) [6].

Glucagon is a hormone with well-characterised effects on glycaemic control and energy expenditure [7]. GLP-1 is the classical incretin hormone, increasing insulin secretion from pancreatic beta cells in a glucose-dependent manner [8]. GLP1 also possesses a number of other beneficial diabetesprotective actions that include decreasing glucagon secretion and increasing satiety and insulin sensitivity [9]. This favourable biological action profile has been successful for the progression of a number of GLP-1-based compounds to the diabetes clinic [10]. Liberation of the related 33-aminoacid product GLP-2, by PC $1 / 3$, yields a peptide with important positive biological actions on intestinal growth, bone breakdown and neuroprotection [6]. Interestingly, OXM is a peptide hormone that can increase insulin secretion and reduce body weight by dual activation of GLP-1 receptors (GLP-1Rs) and glucagon receptors (glucagon-Rs), respectively [11-13]. The relative affinity of OXM for GLP-1 - and glucagon-Rs has not been fully verified, although studies do confirm that OXM has a much weaker affinity than the native peptides for these receptors [14]. Nonetheless, a dual effect is beneficial since activation of glucagon-Rs will induce catabolic effects that favour weight loss, while GLP-1R agonism will modulate glucose homeostasis [15]. Thus, it follows that modification of the structure of glucagon could yield useful therapeutic agents for obesity-related diabetes.

Therefore, in the present study, we have generated $\mathrm{N}$ acetyl-glucagon and (D-Ser ${ }^{2}$ )glucagon-N-terminally modified peptide analogues of glucagon. Furthermore, to promote potential GLP-1R interactions, the nine C-terminal amino acid residues of exendin(1-39) were added to (D-Ser ${ }^{2}$ glucagon to create the novel compound (D-Ser ${ }^{2}$ )glucagon-exe (Table 1). Here we establish the metabolic stability and in vitro insulinreleasing activity of all three analogues compared with native glucagon. We also demonstrate beneficial diabetes-protective actions of (D-Ser ${ }^{2}$ glucagon-exe, and confirm activation of the glucagons- and GLP-1Rs to be key in this respect. Finally, the in vivo therapeutic potential of $\left(\mathrm{D}-\mathrm{Ser}^{2}\right)$ glucagon-exe was assessed using obese high-fat-fed mice with prominent beneficial metabolic effects noted on glycaemic status, body weight control, insulin sensitivity, pancreatic morphology and overall energy balance. The results provide experimental evidence that enzyme-resistant (D-Ser ${ }^{2}$ )glucagon-exe may provide an effective novel means of treating obesity-related diabetes.

\section{Methods}

Peptides Glucagon, $N$-acetyl-glucagon, (D-Ser ${ }^{2}$ )glucagon and (D-Ser ${ }^{2}$ )glucagon-exe were synthesised by GL Biochem (Shanghai, China). Amino acid sequences and molecular mass data are provided in Table 1. Observed molecular masses for all peptides corresponded closely to theoretical values, confirming structural identity.

Dipeptidyl peptidase IV stability The stability of peptides to degradation by dipeptidyl peptidase IV (DPP IV) was assessed as described previously [13]. Briefly, peptides (40 $\mu \mathrm{g})$ were incubated at $37^{\circ} \mathrm{C}$ in $50 \mathrm{mmol} / 1$ triethanolamine- $\mathrm{HCl}$ buffer

Table 1 Amino acid sequence of peptides together with RP-HPLC retention times, MALDI-ToF MS and DPP IV stability

\begin{tabular}{|c|c|c|c|c|c|}
\hline Peptide & Sequence & $\begin{array}{l}\text { Retention } \\
\text { time (min) }\end{array}$ & $\begin{array}{l}\text { Experimental } \\
\text { mass (Da) }\end{array}$ & $\begin{array}{l}\text { Theoretical } \\
\text { mass (Da) }\end{array}$ & $\begin{array}{l}\text { Intact peptide } \\
\text { after } 8 \mathrm{~h}(\%)\end{array}$ \\
\hline Glucagon & HSQGTFTSDYSKYLDSRRAQDFVQWLMNT & 23.5 & $3,483.7$ & $3,482.82$ & 44 \\
\hline$N$-Acetyl-glucagon & Ac-HSQGTFTSDYSKYLDSRRAQDFVQWLMNT & 25.4 & $3,524.4$ & $3,524.6$ & 100 \\
\hline$\left(D-\right.$ Ser $\left.^{2}\right)$ glucagon & H[D $\mathbf{S}]$ GTFTSDYSKYLDSRRAQDFVQWLMNT & 23.2 & $3,482.7$ & $3,482.82$ & 100 \\
\hline$\left(\mathrm{D}-\mathrm{Ser}^{2}\right)$ glucagon-exe & $\mathrm{H}\left[{ }_{D} \mathbf{S}\right]$ QGTFTSDYSKYLDSRRAQDFVQWLMNTPSSGAPPPS & 35.5 & $4,259.9$ & $4,260.66$ & 100 \\
\hline
\end{tabular}

Values represent the $\%$ intact parent peptide remaining relative to parent peptide present at $0 \mathrm{~h}$ as determined from HPLC peak area data

Peptides were purified by RP-HPLC and retention times recorded. Purified samples were subsequently mixed with $\alpha$-cyano-4-hydroxy-1-cinnamic acid, applied to a sample plate of a Voyager-DE Biospectrometry Workstation and experimental $\mathrm{m} / \mathrm{z}$ ratio vs relative peak intensity determined

Chemical modifications are denoted in bold (D represents the D-isomer)

MALDI-ToF, matrix-assisted laser desorption ionisation-time of flight 
(pH 7.8) containing $5 \mathrm{mU}$ DPP IV in a final volume of $500 \mu \mathrm{l}$. Enzymatic reactions were terminated by addition of trifluoroacetic acid/ $\mathrm{H}_{2} \mathrm{O}(10 \mu \mathrm{l}, 10 \%$ [vol./vol.] $)$ and stored at $-20^{\circ} \mathrm{C}$. Reactions products were applied to a Phenomenex C-8 analytical column $(250 \times 4.60 \mathrm{~mm})($ Phenomenex, Macclesfield, UK) and intact peptide, together with any degradation fragments, was separated using reverse-phase (RP) HPLC. HPLC peak area data were determined by UV2000 UV/Vis Detector (Thermo Separation Products, Hemel Hempstead, UK) and the percentage of intact peptide remaining at $8 \mathrm{~h}$ was expressed relative to HPLC peak area at $0 \mathrm{~h}$.

In vitro insulin secretion Clonal BRIN-BD11 cells were used to determine peptide-induced insulin release [16]. Cells were seeded into 24-well plates (Orange Scientific, Brainel'Alleud, Belgium) at a density of $1.0 \times 10^{5}$ cells per well and cultured overnight at $37^{\circ} \mathrm{C}$ to form cell monolayers. Culture medium was removed and $1.0 \mathrm{ml} \mathrm{KRB}(115 \mathrm{mmol} / \mathrm{l}$ $\mathrm{NaCl}, 4.7 \mathrm{mmol} / 1 \mathrm{KCl}, 1.28 \mathrm{mmol} / \mathrm{CaCl}_{2}, 1.2 \mathrm{mmol} / 1$ $\mathrm{MgSO}_{4}, 1.2 \mathrm{mmol} / 1 \mathrm{KH}_{2} \mathrm{PO}_{4}, 25 \mathrm{mmol} / \mathrm{l}$ HEPES and $10 \mathrm{mmol} / \mathrm{l} \mathrm{NaHCO} 3 ; \mathrm{pH} 7.4$ with $\mathrm{NaOH}$ ), supplemented with $0.1 \%$ (wt/vol.) BSA and $1.1 \mathrm{mmol} / 1$ glucose, was added to each well. Cells were incubated for $40 \mathrm{~min}$ at $37^{\circ} \mathrm{C}$, after which the buffer was removed and replaced with fresh KRB $(1.0 \mathrm{ml})$ supplemented with $5.6 \mathrm{mmol} / 1$ glucose, alanine, glucagon or a range of peptide concentrations $\left(10^{-12}\right.$ to $\left.10^{-6} \mathrm{~mol} / \mathrm{l}\right)$, as shown in Fig. 1. After $20 \mathrm{~min}$ incubation at $37^{\circ} \mathrm{C}$, the buffer was removed and stored at $-20^{\circ} \mathrm{C}$ for subsequent measurement of insulin by radioimmunoassay [17].

In vitro cAMP production Chinese hamster lung (CHL) cells transfected with either the human glucose-dependent insulinotropic polypeptide (GIP) receptor (GIP-R) or human GLP-1R, as well as human embryonic kidney (HEK293) cells transfected with the human glucagon- $R$, were used to assess effects on cAMP production [18]. Cells were seeded (200,000 cells per well) into 96-well plates (Nunc, Fisher Scientific, Loughborough, UK) and washed with Hanks' balanced salt solution buffer before incubation with test peptides $\left(10^{-12}\right.$ and $\left.10^{-6} \mu \mathrm{mol} / \mathrm{l}\right)$ in the presence of $200 \mu \mathrm{mol} / 13$-isobutyl-1methylxanthine for $20 \mathrm{~min}$ at $37^{\circ} \mathrm{C}$. After incubation, medium was removed and cells were lysed before measurement of cAMP using Parameter cAMP assay (R\&D Systems, Abingdon, UK) according to the manufacturer's instructions.

Animals Male NIH Swiss mice (8 weeks old; Harlan, Blackthorn, UK) were housed in an air-conditioned room at $22 \pm$ $2^{\circ} \mathrm{C}$ with a $12 \mathrm{~h}$ light:12 h dark cycle (08:00-20:00 hours). The mice had free access to drinking water and either a standard chow diet $(10 \%$ fat, $30 \%$ protein, $60 \%$ carbohydrate; percentage of total energy $12.99 \mathrm{~kJ} / \mathrm{g}$; Trouw Nutrition, Cheshire, UK) or a high-fat diet (45\% fat, $20 \%$ protein and $35 \%$ carbohydrate; percentage of total energy of $26.15 \mathrm{~kJ} / \mathrm{g}$;
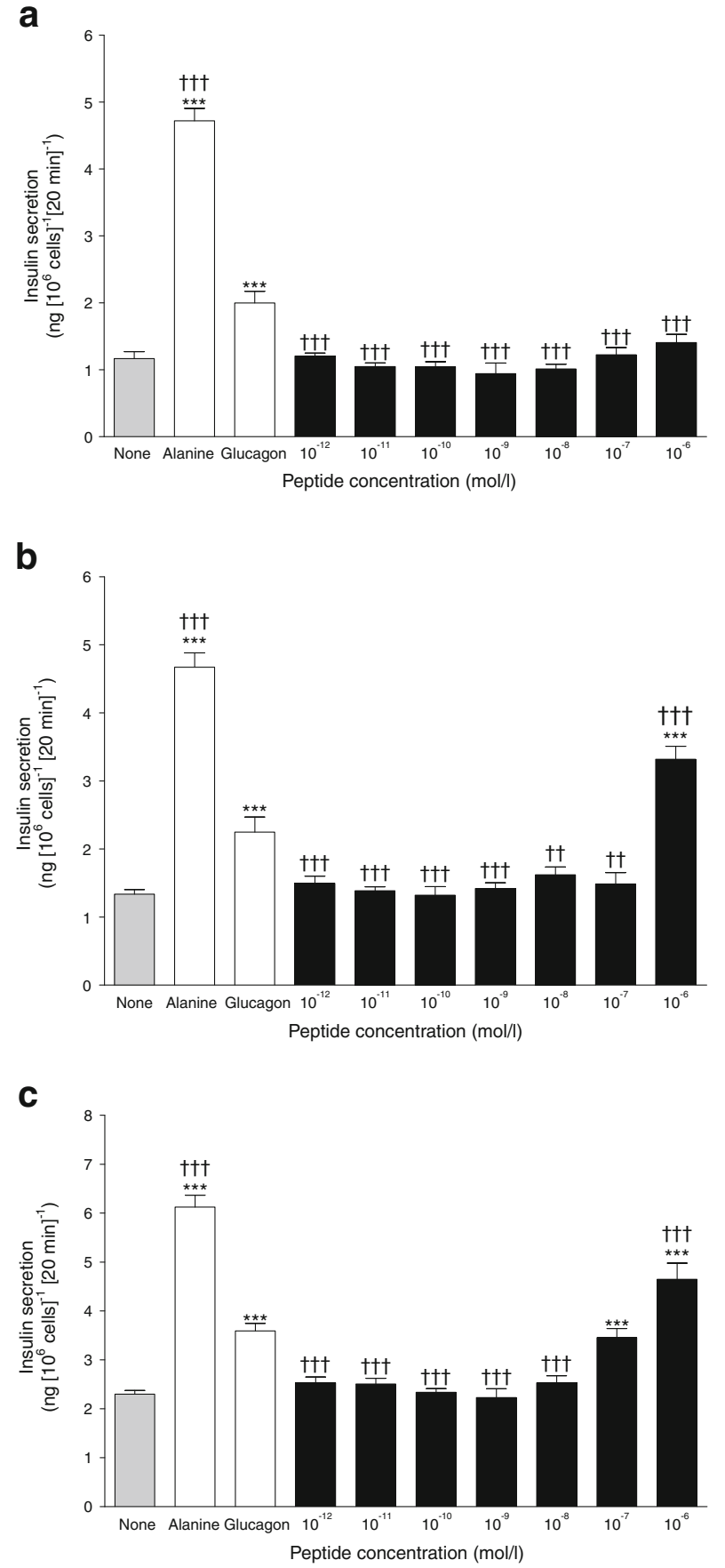

Fig. 1 Acute effects of $N$-acetyl-glucagon (a), (D-Ser $\left.{ }^{2}\right)$ glucagon (b) and (D-Ser ${ }^{2}$ )glucagon-exe (c) on insulin secretion from BRIN-BD11 cells. Grey bars, $5.6 \mathrm{mmol} / 1$ glucose control; white bars, $20 \mathrm{mmol} / 1$ alanine or $10^{-7} \mathrm{~mol} / \mathrm{l}$ glucagon; black bars, $N$-acetyl-glucagon (a), (D-Ser $\left.{ }^{2}\right)$ glucagon (b) or (D-Ser ${ }^{2}$ glucagon-exe (c). Values represent means \pm SEM, $n=8$. $* * * p<0.001$ compared with $5.6 \mathrm{mmol} / 1$ glucose alone; ${ }^{\dagger \dagger} p<0.01$ and ${ }^{\dagger \dagger} p<0.001$ compared with $10^{-7} \mathrm{~mol} / \mathrm{l}$ glucagon alone

Special Diets Service, Essex, UK) for 3 months, before commencement of experiments. Other experiments used 14-weekold wild-type C57BL/6J and GLP-1R knockout (GLP-1R $\mathrm{KO})$ mice, on the same genetic background, originally derived 
from breeding pairs kindly supplied by D. Drucker (Banting \& Best Diabetes Centre, University of Toronto, Canada). These mice were fed standard chow diet ad libitum. All animal studies were performed in accordance with the UK Animals (Scientific Procedures) Act 1986. No adverse effects were observed following administration of any of the peptides.

Acute and persistent effects on plasma glucose and insulin responses For acute studies, mice were administered an intraperitoneal injection of saline vehicle $(0.9 \%$ [wt/vol.] $\mathrm{NaCl})$, glucagon or (D-Ser ${ }^{2}$ )glucagon-exe (each at $25 \mathrm{nmol} / \mathrm{kg}$ body weight). Blood samples were taken immediately before $(t=0)$ and at 15, 30 and $60 \mathrm{~min}$ post injection. In another series of experiments, (D-Ser $\left.{ }^{2}\right)$ glucagon-exe $(25 \mathrm{nmol} / \mathrm{kg})$ was injected 4,8 or $12 \mathrm{~h}$ before an intraperitoneal challenge with glucose $(18 \mathrm{mmol} / \mathrm{kg})$. Blood samples were taken immediately before $(t=0)$ and at 15, 30 and 60 min post glucose injection. Blood glucose was measured using an Ascencia Microfill Blood Glucose Meter (Bayer, Newbury, UK). Blood samples for plasma insulin analysis were collected into fluoride-coated microcentrifuge tubes (Sarstedt, Numbrecht, Germany) and centrifuged at $12,000 \mathrm{~g}$ at $4^{\circ} \mathrm{C}$ for 3 min using a Beckman microcentrifuge (Beckman Instruments, High Wycombe, UK). Resulting plasma samples were collected and stored at $-20^{\circ} \mathrm{C}$ until determination of insulin [17].

Effects of twice-daily administration of (D-Ser $\left.{ }^{2}\right)$ glucagon-exe on metabolic variables High-fat-fed mice $(n=8)$ received twice-daily (09:30 and 16:00 hours) injections of saline vehicle $(0.9 \%$ [wt/vol.] $\mathrm{NaCl})$ or $\left(\mathrm{D}-\mathrm{Ser}^{2}\right)$ glucagon-exe $(25 \mathrm{nmol} / \mathrm{kg}$ ) for 28 days. Food intake, body weight and non-fasting plasma glucose and insulin were measured every 3-4 days. Glucose tolerance $(18 \mathrm{mmol} / \mathrm{kg})$ and insulin sensitivity (25 U/kg, intraperitoneal) tests were performed at the end of the study in non-fasted mice. In addition, on day 28, mice were placed in Complete Laboratory Animal Monitoring System (CLAMS) metabolism chambers (Columbus Instruments, Columbus, OH, USA) following the normal daily injection at 09:30 hours. Following an acclimatisation period of $24 \mathrm{~h}$, the consumption of $\mathrm{O}_{2}$, production of $\mathrm{CO}_{2}$, respiratory exchange ratio (RER), energy expenditure and locomotor activity of each mouse was determined as described previously [19]. Pancreatic tissues were also excised for the assessment of islet morphology as described elsewhere [20].

Statistical analysis Results are expressed as mean \pm SEM and values were compared using repeated-measures ANOVA or one-way ANOVA (followed by the Student-Newman-Keuls post hoc test) or by Student's unpaired $t$ test as appropriate. Incremental plasma insulin and glucose AUC was calculated using GraphPad Prism (version 5.0; San Diego, CA, USA). Groups of data were considered to be significantly different if $p<0.05$.

\section{Results}

Peptide characterisation and DPP IV stability Incubation with DPP IV rapidly degraded native glucagon $(44 \%$ intact peptide remained at $8 \mathrm{~h}$ ). However, none of the other analogues tested displayed any degradation when incubated with DPP IV for up to $8 \mathrm{~h}$ (Table 1).

In vitro insulin secretion and cAMP production Native glucagon, (D-Ser $\left.{ }^{2}\right)$ glucagon and (D-Ser $\left.{ }^{2}\right)$ glucagon-exe evoked significant insulin responses from BRIN BD11 cells compared with $5.6 \mathrm{mmol} / \mathrm{l}$ glucose control (Fig. $1 \mathrm{~b}, \mathrm{c}$ ). $\mathrm{N}$-acetylglucagon was ineffective (Fig. 1a) whereas (D-Ser ${ }^{2}$ )glucagonexe was the most significant secretagogue at $10^{-7}$ and $10^{-6} \mathrm{~mol} / \mathrm{l}$ (Fig. 1c). The cAMP production capability of $\left(D-\mathrm{Ser}^{2}\right)$ glucagon-exe was then examined in glucagon-R-, GIP-R- and GLP-1R-transfected cells (Fig. 2). (D-Ser ${ }^{2}$ )glucagon-exe induced significant $(p<0.001)$ cAMP generation in glucagon-R- and GLP-1Rtransfected cells at concentrations of $10^{-8} \mathrm{~mol} / \mathrm{l}$ and above when compared with control (Fig. 2a, c). Moreover, (D$\mathrm{Ser}^{2}$ )glucagon-exe was significantly $(p<0.01$ to $p<0.001)$ more efficacious than native glucagon in glucagon-R-

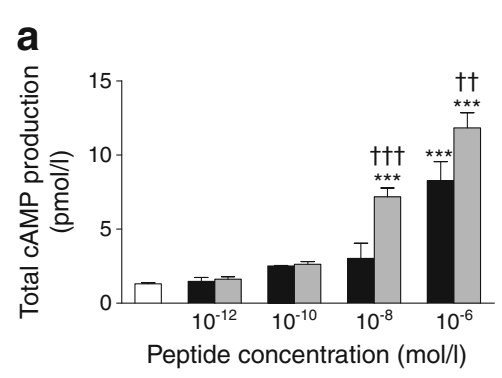

Fig. 2 Effect of (D-Ser $\left.{ }^{2}\right)$ glucagon-exe on cAMP production in glucagonR-, GIP-R- and GLP-1R-transfected cells. White bars, control; black bars, glucagon (a), GIP(1-42) (b) or GLP-1 (c); grey bars, (D-Ser $\left.{ }^{2}\right)$ glucagon-exe.
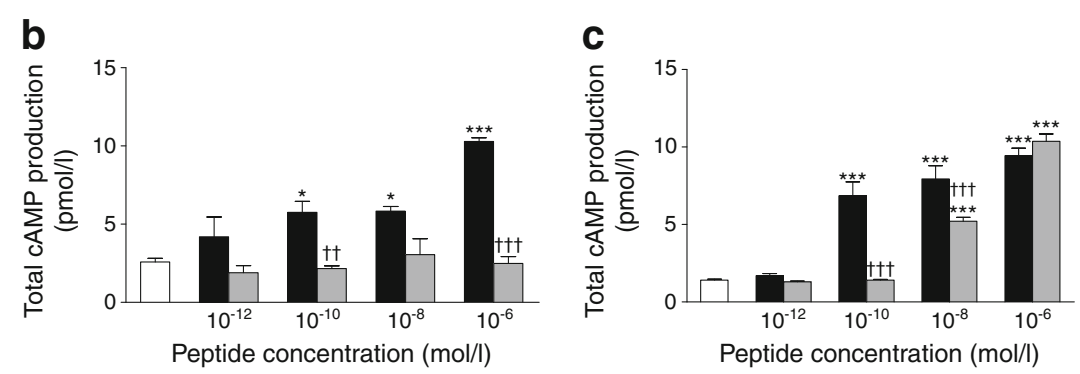

Values represent means \pm SEM, $n=8 .{ }^{*} p<0.05$ and $* * * p<0.001$ compared with control; ${ }^{\dagger} p<0.01$ and ${ }^{\dagger \dagger} p<0.001$ compared with respective native peptide at the same concentration 
transfected cells (Fig. 2a). (D-Ser ${ }^{2}$ )glucagon-exe had no effect on cAMP production in GIP-R-transfected cells (Fig. 2b).

Acute effects on plasma glucose and insulin Figure 3 displays the plasma glucose and insulin responses to administration of the various peptides in mice. Whereas $\mathrm{N}$-acetyl-glucagon and $\left(\mathrm{D}-\mathrm{Ser}^{2}\right)$ glucagon were more hyperglycaemic than native glucagon (Fig. 3a, b), (D-Ser ${ }^{2}$ )glucagon-exe was devoid of significant hyperglycaemic properties (Fig. 3c). All peptides increased plasma insulin concentrations, with particularly prominent effects observed with $\left(\mathrm{D}-\mathrm{Ser}^{2}\right)$ glucagon and $\left(\mathrm{D}-\mathrm{Ser}^{2}\right)$ glucagon-exe (Fig. 3e, f). Accordingly, (D-Ser ${ }^{2}$ )glucagon-exe was taken forward for further evaluation.

Persistent effect of (D-Ser $\left.{ }^{2}\right)$ glucagon-exe on glucose lowering and insulin release As evident from electronic supplementary material (ESM) Fig. 1a-f, mice treated with (D-Ser ${ }^{2}$ )glucagonexe 4,8 or $12 \mathrm{~h}$ previously displayed a significant $(p<0.01$ to $p<0.001)$ decrease in plasma glucose with concomitant increases in plasma insulin levels $(p<0.05$ to $p<0.01)$ in response to a glucose intraperitoneal load.
Acute effects on plasma glucose and insulin in GLP-1R KO mice Administration of native glucagon to wild-type C57BL/6J (Fig. 4a, c) or GLP-1R KO (Fig. 4b, d) mice induced characteristic glucose- and insulin-elevating effects, when compared with saline vehicle alone. In contrast, treatment with (D-Ser $\left.{ }^{2}\right)$ glucagon-exe did not significantly alter overall blood glucose concentrations in either mouse model when compared with saline control (Fig. 4a, b). Small but significant $(p<0.05$ to $p<0.01)$ increases in plasma insulin levels were observed at 15,30 and $60 \mathrm{~min}$ post (D$\mathrm{Ser}^{2}$ )glucagon-exe injection in GLP-1R KO mice (Fig. 4d). However, significant $(p<0.001)$ increases in overall 0-60 min AUC insulin secretory response were noted in C57BL/6 J (Fig. 4c) but not GLP-1R KO mice (Fig. 4d).

Effects of twice-daily administration of (D-Ser $\left.{ }^{2}\right)$ glucagon-exe in high-fat-fed mice Twice-daily administration of $\left(\mathrm{D}-\mathrm{Ser}^{2}\right)$ glucagon-exe significantly $(p<0.01)$ reduced body weight compared with saline-treated controls (Fig. 5a). Overall energy intake was also reduced by (D-Ser $\left.{ }^{2}\right)$ glucagon-exe treatment (Fig. 5b). In addition, non-fasted plasma glucose concentrations were significantly $(p<0.05$ to $p<0.001)$
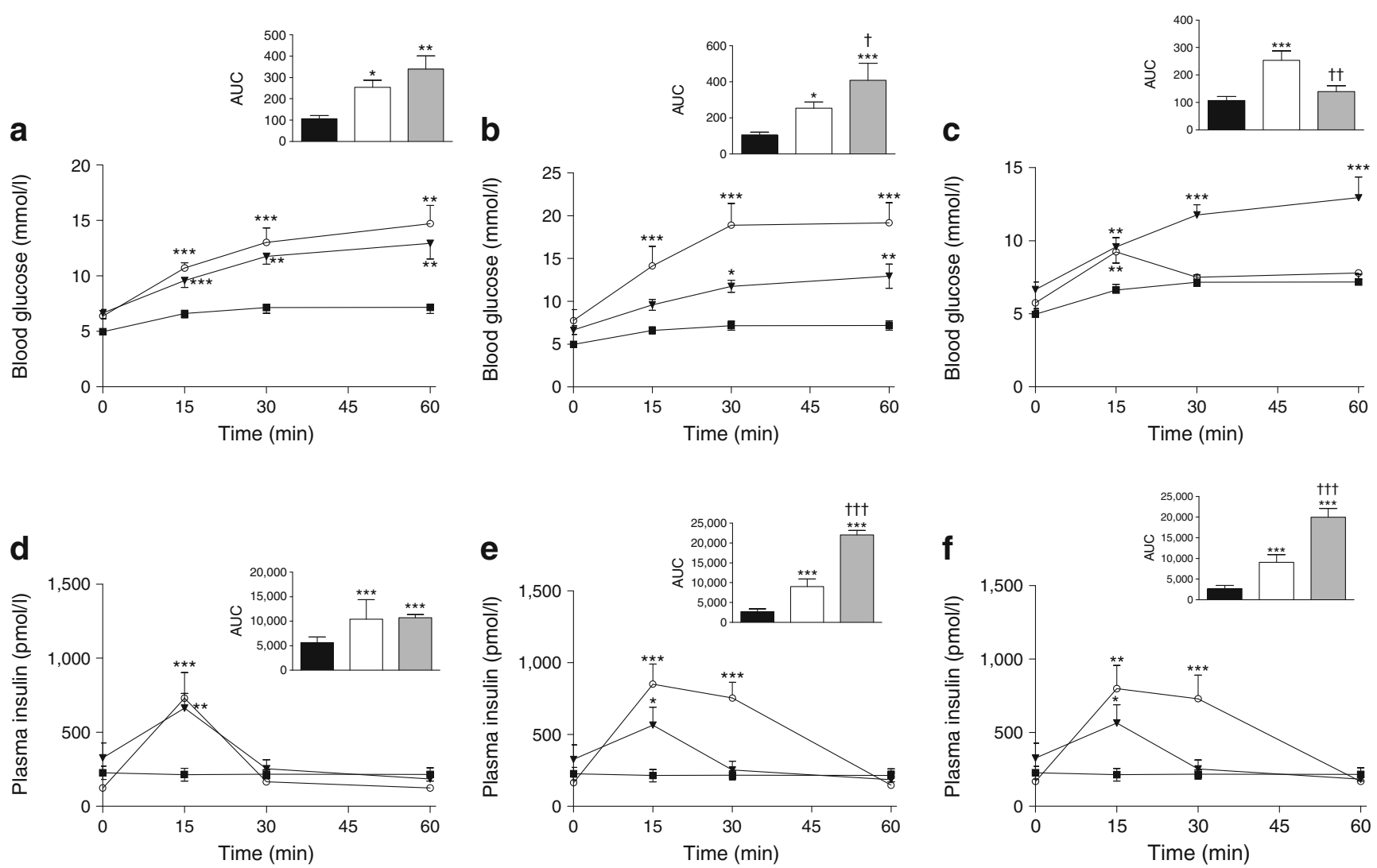

Fig. 3 Acute effects of $N$-Acetyl-glucagon, (D-Ser ${ }^{2}$ )glucagon and $\left(\mathrm{D}-\mathrm{Ser}^{2}\right)$ glucagon-exe on glucose and insulin responses in normal mice. Insets show AUC values for 0-60 min post injection. Squares and black bars, saline; triangles and white bars, glucagon; circles and grey bars,

$N$-Acetyl-glucagon (a), (D-Ser $\left.{ }^{2}\right)$ glucagon (b) or (D-Ser $\left.{ }^{2}\right)$ glucagon-exe (c). Values are means \pm SEM for eight mice. ${ }^{*} p<0.05, * * p<0.01$ and $* * * p<0.001$ compared with respective saline controls; ${ }^{\dagger} p<0.05$, ${ }^{\dagger} p<0.01$ and ${ }^{\dagger \dagger} p<0.001$ compared with glucagon 
Fig. 4 Acute effects of (D-Ser ${ }^{2}$ )glucagon-exe on glucose and insulin responses in GLP-1R $\mathrm{KO}$ mice. Blood glucose $(\mathbf{a}, \mathbf{b})$ and plasma insulin $(\mathbf{c}, \mathbf{d})$ concentrations were measured before and after intraperitoneal administration of saline vehicle, glucagon or (D-Ser $\left.{ }^{2}\right)$ glucagon-exe (both at $25 \mathrm{nmol} / \mathrm{kg}$ ) in C57BL/6J (a, c) and GLP-1R KO mice $(\mathbf{b}, \mathbf{d})$. Insets show AUC values for 0-60 min post injection. Squares and black bars, saline; triangles and white bars, glucagon; circles and grey bars, (D-Ser ${ }^{2}$ )glucagon-exe. Values represent means \pm SEM for eight mice. ${ }^{*} p<0.05,{ }^{*} p<0.01$ and $* * * p<0.001$ compared with saline alone; ${ }^{\dagger \dagger} p<0.001$ compared with glucagon alone
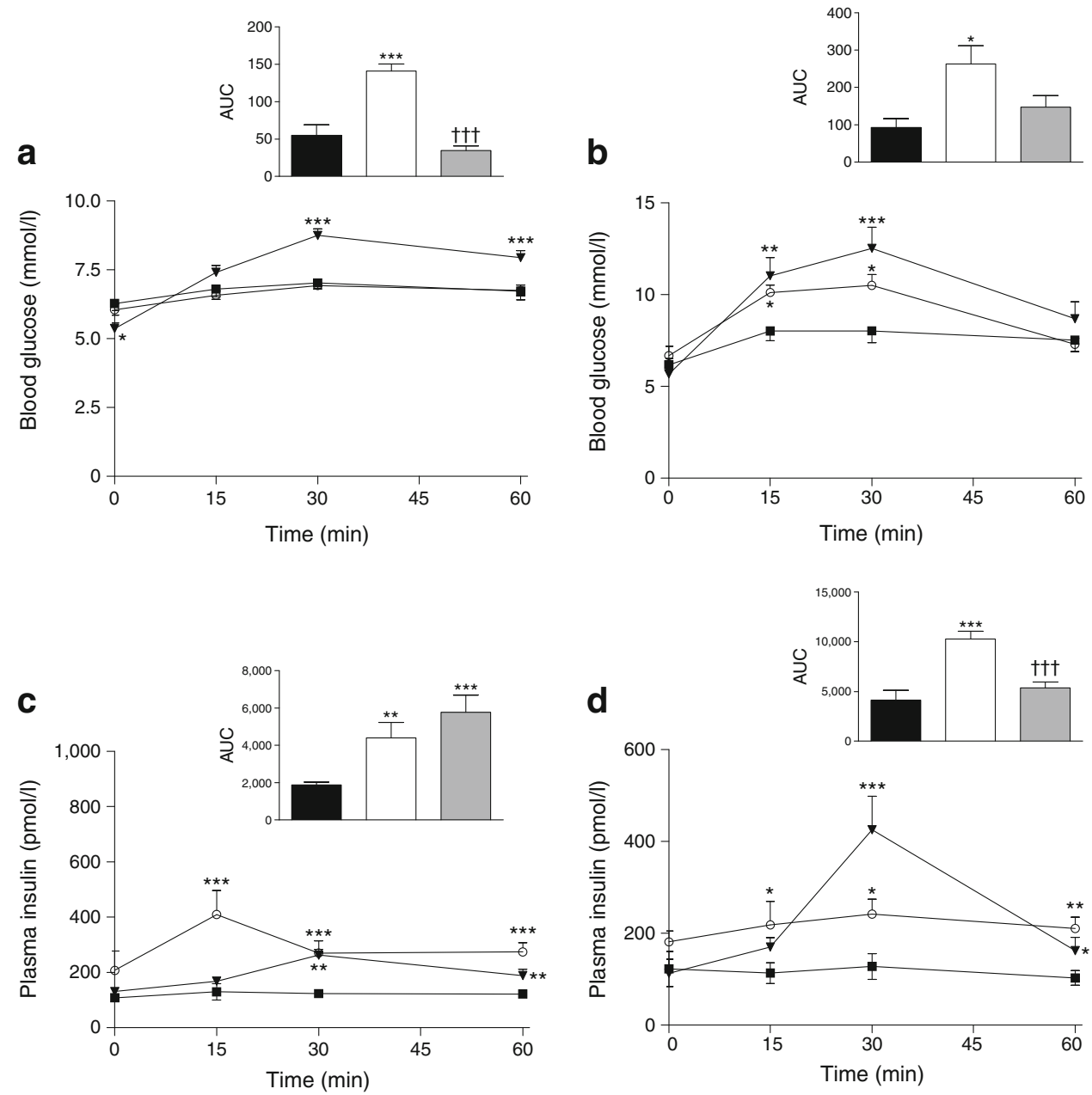

decreased from day 9 onwards (Fig. 5c) while plasma insulin levels were significantly $(p<0.05$ to $p<0.001)$ elevated by day 25 (Fig. 5d). Beneficial metabolic effects on body weight, plasma glucose and insulin persisted, to a lesser effect, after the cessation of treatment (Fig. 5a, c, d).

Effects of (D-Ser $\left.{ }^{2}\right)$ glucagon-exe on glucose tolerance and insulin sensitivity in high-fat-fed mice Administration of (D-Ser ${ }^{2}$ )glucagon-exe twice daily for 28 days significantly $(p<0.01)$ improved the overall glycaemic excursion after a glucose load (Fig. 6a, c). In addition, the glucose-mediated insulinotropic response was significantly elevated in terms of individual $(p<0.01$ to $p<0.001)$ and overall AUC $(p<0.001)$ values in the (D-Ser $\left.{ }^{2}\right)$ glucagon-exe treatment group (Fig. 6a, c). Two weeks after cessation of treatment with (D-Ser $\left.{ }^{2}\right)$ glucagonexe, the glycaemic excursion and insulin response remained significantly $(p<0.05$ to $p<0.001)$ improved (Fig. 6b, d). ESM Fig. 2 depicts the effect of (D-Ser $\left.{ }^{2}\right)$ glucagon-exe on insulin sensitivity on day 28 (ESM Fig. 2a, c) and two weeks after treatment cessation (ESM Fig. 2b, d); (D-Ser ${ }^{2}$ )glucagon-exe treatment resulted in significantly $(p<0.001)$ improved insulin sensitivity at both time points examined.
Effects of (D-Ser $\left.{ }^{2}\right)$ glucagon-exe on metabolic rate and energy expenditure in high-fat-fed mice (D-Ser $\left.{ }^{2}\right)$ glucagon-exe treatment significantly $(p<0.05)$ increased $\mathrm{O}_{2}$ consumption on day 28 but had no effect on $\mathrm{CO}_{2}$ production (ESM Fig. 3a, b). RER was not changed but energy expenditure was significantly $(p<0.01)$ increased in $\left(\mathrm{D}-\mathrm{Ser}^{2}\right)$ glucagon-exe-treated mice (ESM Fig. 3c, d). In addition, (D-Ser ${ }^{2}$ )glucagon-exe-treated mice displayed significantly $(p<0.01)$ increased ambulatory activity during the dark phase, but not the light phase, as assessed by X-beam breaks on day 28 (ESM Fig. 4a, b). These mice also exhibited significantly $(p<0.001)$ increased rearing and jumping episodes during the dark phase, but not during the light phase (ESM Fig. 4c, d).

Effects of $\left(D-S e r^{2}\right)$ glucagon-exe on pancreatic islet morphology in high-fat-fed mice (D-Ser ${ }^{2}$ )glucagon-exe significantly increased pancreatic islet number $(p<0.001)$, as well as overall islet $(p<0.05)$ and beta cell $(p<0.05)$ areas (ESM Fig. $5 \mathrm{a}-\mathrm{c})$. These beneficial morphological changes persisted two weeks after cessation of treatment (ESM Fig. 5d-f). 

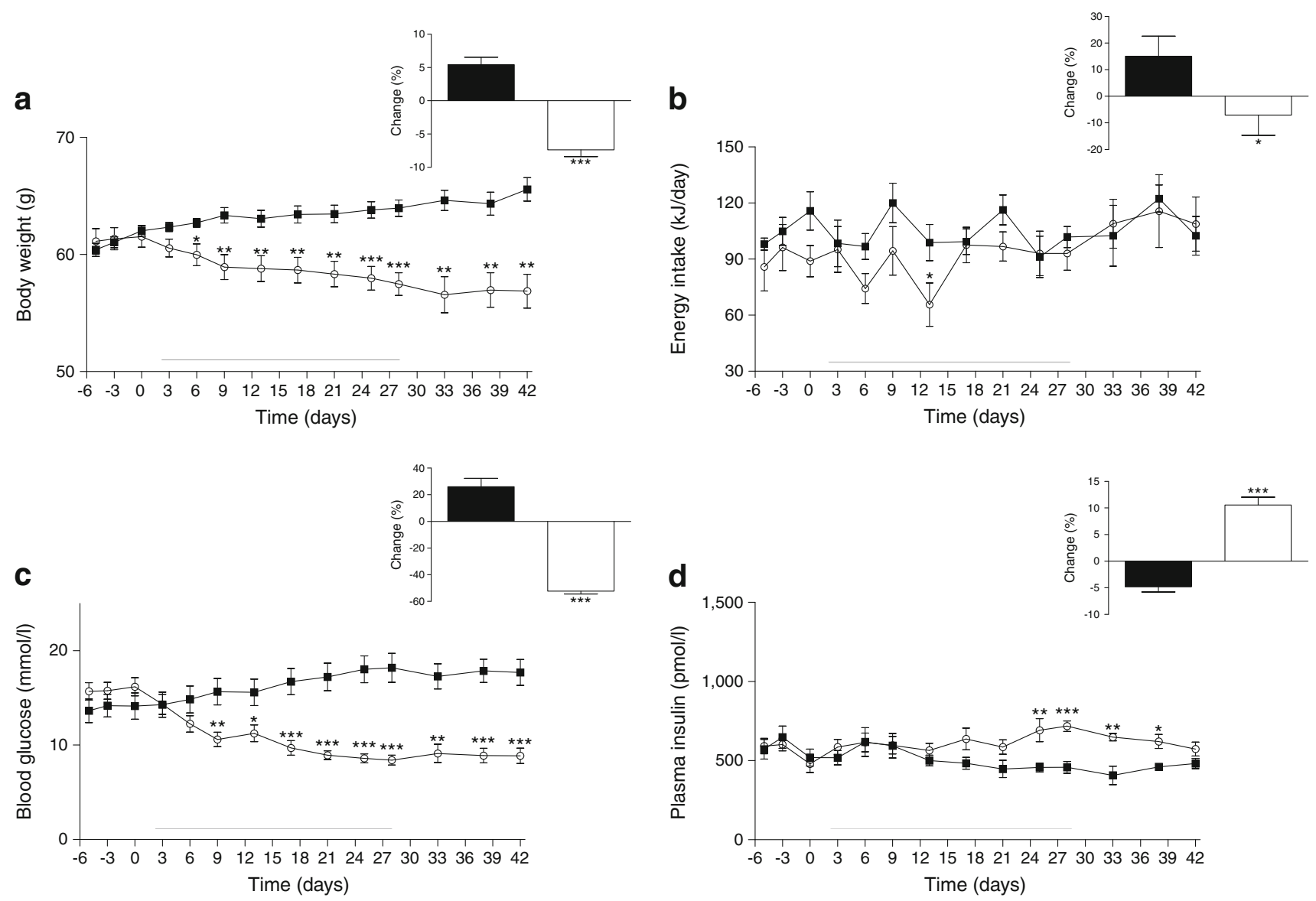

Fig. 5 Effects of twice-daily injection, for 28 days, of (D-Ser ${ }^{2}$ )glucagonexe on body weight (a), energy intake (b), non-fasting plasma glucose (c) and plasma insulin (d) in high-fat-fed mice. Variables were measured at 3-4 day intervals for 5 days before, 4 weeks during (indicated by black horizontal bar) and 2 weeks following cessation of treatment (twice-daily

\section{Discussion}

The past ten years have witnessed major advances in the exploitation of peptide therapeutics for diabetes as demonstrated by the clinical use of GLP-1 and amylin mimetics [21, 22]. OXM and other dual- or triple-acting hybrid peptides have also been developed, incorporating the therapeutic potential of not only GLP-1R activity but also that of glucagonand GIP-Rs [23]. Thus, it appears that stimulation of insulin secretion from pancreatic beta cells may overcome the hyperglycaemic actions of glucagon and allow exploitation of its beneficial effects on food intake, fat mobilisation and energy expenditure [24]. This study has therefore examined novel glucagon analogues in an attempt to reveal new molecular approaches to type 2 diabetes therapy.

Whereas native glucagon was susceptible to DPP IVmediated degradation, the analogues that possessed either (D-Ser ${ }^{2}$ ) or $N$-acetyl modifications were stable. This is consistent with previous studies indicating that DPP IV cannot cleave $\mathrm{N}$-terminally modified forms of glucagon

injection of (D-Ser ${ }^{2}$ )glucagon-exe, $25 \mathrm{nmol} / \mathrm{kg}$ ). Insets show \% change from basal, with day 0 as baseline. Squares and black bars, saline; circles and white bars, $\left(\mathrm{D}-\mathrm{Ser}^{2}\right)$ glucagon-exe. Values are expressed as means \pm SEM for eight mice. ${ }^{*} p<0.05,{ }^{* *} p<0.01$ and $* * * p<0.001$ compared with saline-treated high-fat-fed mice

$[25,26]$. (D-Ser $\left.{ }^{2}\right)$ glucagon and (D-Ser $\left.{ }^{2}\right)$ glucagon-exe also stimulated insulin secretion from clonal beta cells, whereas $N$-acetyl-glucagon was ineffective in this regard. These observations not only highlight the insulinreleasing properties of glucagon-like molecules [27] but also demonstrate that manipulation of the N-terminus of glucagon can hinder biological activity [28], as was the case for $\mathrm{N}$-acetyl-glucagon. Intriguingly, this compound did possess insulinotropic actions when administered to mice, coupled with potent hyperglycaemic effects. Mechanisms responsible for the indirect insulinotropic effect are unclear but might simply reflect beta cell stimulation by raised glucose [24]. In contrast to the acetylated analogue, (D-Ser $\left.{ }^{2}\right)$ glucagon and $\left(\mathrm{D}-\mathrm{Ser}^{2}\right)$ glucagon-exe both possessed very pronounced insulin-releasing actions. However, unlike glucagon and the other two analogues, (D-Ser ${ }^{2}$ )glucagon-exe did not induce elevations in blood glucose. This profile of (D-Ser $\left.{ }^{2}\right)$ glucagon-exe also differs from the biological actions of native OXM, which has previously been shown to increase glucose production 
Fig. 6 Effects of twice-daily injection, for 28 days, of $\left(\mathrm{D}-\mathrm{Ser}^{2}\right)$ glucagon-exe on glucose and insulin responses to exogenous glucose immediately following (a, c) and 2 weeks after $(\mathbf{b}, \mathbf{d})$ cessation of treatment in high-fat-fed mice. Insets show overall plasma glucose and insulin AUC values for 0-105 min. Squares and black bars, saline; circles and white bars, (D-Ser ${ }^{2}$ )glucagon-exe. Values are expressed as means \pm SEM for eight mice. $* p<0.05, * * p<0.01$ and $* * * p<0.001$ compared with saline-treated high-fat-fed mice
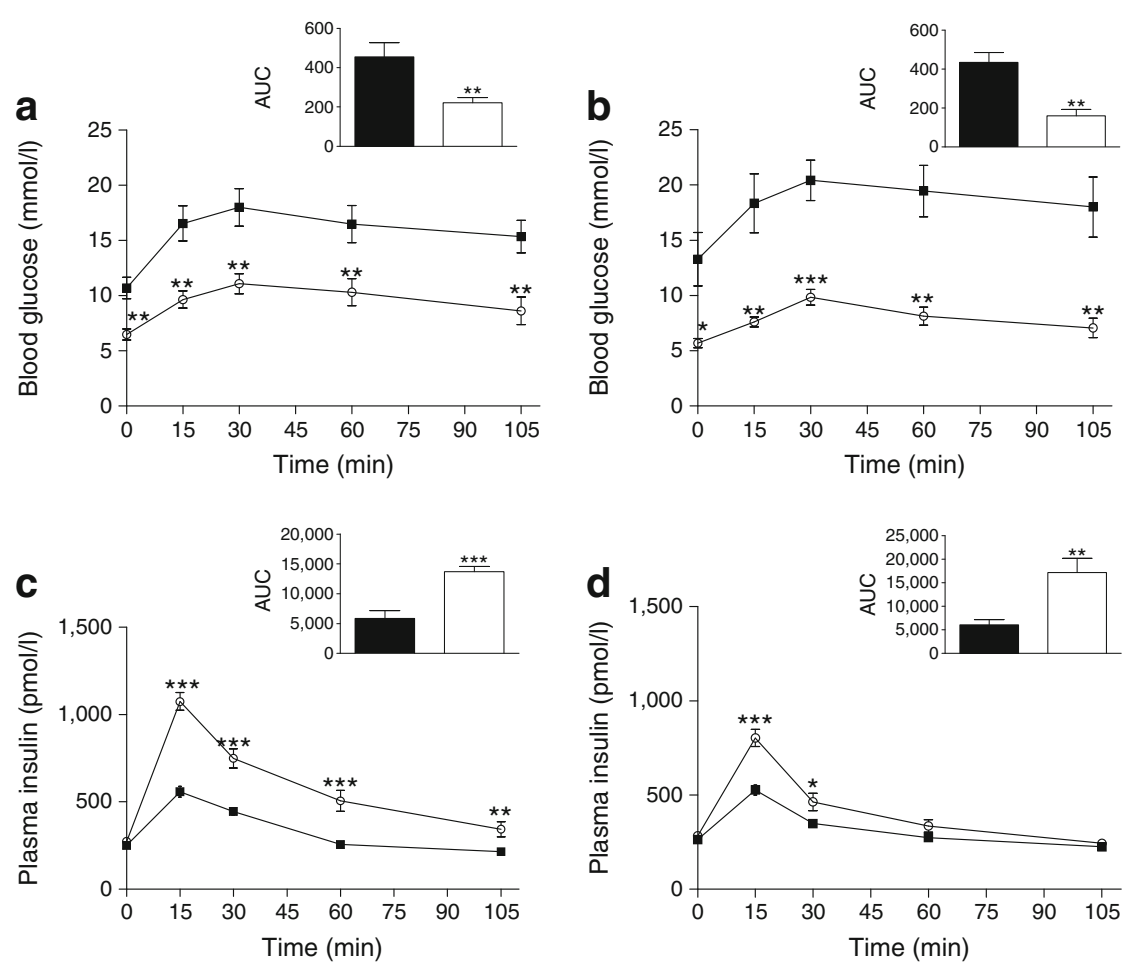

during a hyperinsulinaemic-euglycaemic clamp in mice [29]. Thus, $\left(\mathrm{D}-\mathrm{Ser}^{2}\right)$ glucagon-exe, which consists of the entire glucagon sequence, with a nine amino acid C-terminal extension, may have improved therapeutic use over OXM, similar to exendin(1-39). The C-terminal extension employed for $\left(\mathrm{D}-\mathrm{Ser}^{2}\right)$ glucagon-exe has previously been shown to stabilise peptides, reduce clearance and significantly enhance in vivo potency [30, 31]. Although we do not have an assay for $\left(\mathrm{D}-\mathrm{Ser}^{2}\right)$ glucagon-exe with which to determine pharmacokinetics, bioactivity studies revealed that the glucose-lowering actions of (D-Ser $\left.{ }^{2}\right)$ glucagon-exe were sustained for up to $12 \mathrm{~h}$ after administration. This is consistent with other regulatory peptides that possess similar amino acid substitutions [14, 31, 32].

Further studies were performed to determine which receptors were activated by (D-Ser $\left.{ }^{2}\right)$ glucagon-exe. Investigations using GLP-1R KO mice, revealed that the glucosehomeostatic and, particularly, insulin-releasing actions of $\left(\mathrm{D}-\mathrm{Ser}^{2}\right.$ )glucagon-exe were largely dependent on GLP-1R activation. However, it is likely that glucagon-R activation would be important for beneficial effects on energy regulation $[7,12]$. As such, $\left(\mathrm{D}-\mathrm{Ser}^{2}\right)$ glucagon-exe stimulated cAMP production in glucagon-R- and GLP-1-R-transfected cells with similar or enhanced efficacy when compared with the native peptide. This clearly shows that $\left(\mathrm{D}-\mathrm{Ser}^{2}\right)$ glucagon-exe is a potent dual agonist, with a C-terminal structure quite distinct from OXM [33]. The distinct specificity for incretin receptors [34] was confirmed by the lack of biological activity of $\left(\mathrm{D}-\mathrm{Ser}^{2}\right)$ glucagon-exe in GIP-R-transfected cells. However, competitive receptor binding studies with labelled peptide would ultimately be required to unequivocally confirm which receptors are activated by $\left(\mathrm{D}-\mathrm{Ser}^{2}\right)$ glucagon-exe. Nonetheless, the results from in vitro and acute in vivo studies provide a strong basis for the subsequent 28 day study in high-fat-fed mice.

Chronic treatment, for 28 days, of mice with dietaryinduced obesity with (D-Ser $\left.{ }^{2}\right)$ glucagon-exe resulted in a marked improvement in metabolic status. This included a decreased overall energy intake and a greater than $10 \%$ loss in body weight. Other hybrid peptides that interact with glucagon and GLP-1Rs have been reported previously [35, 36]. However, these peptides function as GLP-1R agonists and glucagon- $\mathrm{R}$ antagonists and as such lack the prominent effects on body weight loss noted in the current study. Circulating glucose levels and intraperitoneal glucose tolerance were significantly improved in (D-Ser $\left.{ }^{2}\right)$ glucagon-exe-treated high-fatfed mice. These beneficial effects are symptomatic of the increased metabolic efficiency that typically accompanies weight loss [7]. In keeping with this, insulin sensitivity was significantly improved by day 28 and this was accompanied by a marked improvement in glucose-mediated insulin secretion. These data clearly support previous suggestions of improved beta cell function and glucose homeostasis following dual activation of glucagon- and GLP-1Rs [13]. Notably we observed a marked expansion of pancreatic islet and beta cell mass, with increased total numbers of islets in $\left(\mathrm{D}-\mathrm{Ser}^{2}\right)$ glucagon-exe-treated mice. This effect is consistent with the view that GLP-1 is a proliferative agent for beta cells 
[37]. Thus, a major component of the beneficial biological actions of (D-Ser ${ }^{2}$ glucagon-exe appears to be mediated by direct effects on the endocrine pancreas.

In an attempt to further clarify the potential mechanisms behind the observed positive effects, we assessed aspects of metabolic rate and energy regulation following 28 days treatment with (D-Ser $\left.{ }^{2}\right)$ glucagon-exe. General locomotor activity and explorative episodes were elevated during the dark phase in (D-Ser $\left.{ }^{2}\right)$ glucagon-exe-treated mice, but unaltered during the light phase. This is a positive effect, given that locomotor activity of mice is already increased during the dark phase [19]. Energy expenditure and $\mathrm{O}_{2}$ consumption were also increased by (D-Ser $\left.{ }^{2}\right)$ glucagon-exe, which may be due in part to increased activity [18]. Such effects, combined with significant reductions in food intake are clearly responsible for the substantial body weight loss [12]. Changes in feeding are likely modulated by both GLP-1- and glucagon-Rs, whereas beneficial effects on energy regulation most likely reflect activation of glucagon-Rs by (D-Ser ${ }^{2}$ )glucagon-exe [24]. However, further studies, such as determining gene expression in metabolically active tissues, would help to elucidate the pathways and underlying beneficial mechanisms observed with $\left(\mathrm{D}-\mathrm{Ser}^{2}\right)$ glucagon-exe treatment.

An important observation in this study was the persistence of beneficial effects following discontinuation of $\left(\mathrm{D}-\mathrm{Ser}^{2}\right)$ glucagon-exe treatment in high-fat-fed mice. This contrasts with the findings of a previous study using a long-acting OXM molecule in $o b / o b$ mice [13]. In the present study body weight, non-fasting circulating glucose, glucose tolerance, insulin sensitivity and pancreatic morphology were still significantly improved in $\left(\mathrm{D}-\mathrm{Ser}^{2}\right)$ glucagonexe-treated mice 14 days after cessation of treatment. This suggests the possibility of change in metabolic programming [38], although persistence of the advantageous effects on blood glucose control could possibly reflect maintained reduction of body weight, which is known to impart positive metabolic effects [20]. The relative beneficial metabolic effects of $\left(\mathrm{D}-\mathrm{Ser}^{2}\right)$ glucagon-exe were comparable with, or indeed superior to, essentially similar studies conducted in our laboratory with the clinically approved GLP-1R agonist exendin-4 [39-41]; (D-Ser $\left.{ }^{2}\right)$ glucagon-exe had superior bodyweight-lowering effects compared with exendin-4 and similar or superior metabolic benefits. Thus, (D-Ser ${ }^{2}$ )glucagonexe has significant potential to be further explored as a possible novel therapeutic compound for the treatment of obesity-related diabetes.

In conclusion, this study demonstrates for the first time that the stable glucagon analogue (D-Ser ${ }^{2}$ )glucagon-exe causes sustained weight loss and improves glucose tolerance, insulin resistance, pancreatic morphology, metabolic rate and energy expenditure in high-fat-fed mice. Thus, (D-Ser $\left.{ }^{2}\right)$ glucagon-exe is a novel enzyme-resistant drug with potential application for the treatment of obesity-related diabetes.
Funding These studies were supported by the Department of Education and Learning, Northern Ireland, University of Ulster selective research funding and a research grant from Diabetes Research and Wellness Foundation.

Duality of interest NI, VAG, FPMO'H and PRF hold shares with Diabetica Ltd, which has patents for exploitation of peptide therapeutics. All other authors declare that there is no duality of interest associated with their contribution to this manuscript.

Contribution statement NI, VAG, FPMO'H and PRF conceived the study, participated in the analysis and interpretation of data, drafted the manuscript and revised it critically for intellectual content. AML, NP and VP participated in the analysis and interpretation of data and drafted the manuscript and revised it critically for intellectual content. All authors approved the final version of the manuscript. VAG is the guarantor of this work.

\section{References}

1. Baggio L, Drucker DJ (2007) Biology of Incretins: GLP-1 and GIP. Gastroenterology 132:2131-2157

2. Thorens B (1995) Glucagon-like peptide-1 and control of insulin secretion. Diabetes Metab 21:311-318

3. McGirr R, Guizzetti L, Dhanvantari S (2013) The sorting of proglucagon to secretory granules is mediated by carboxypeptidase E and intrinsic sorting signals. J Endocrinol 217:229-240

4. Mojsov S, Heinrich G, Wilson IB, Ravazzola M, Orci L, Habener JF (1986) Preproglucagon gene expression in pancreas and intestine diversifies at the level of post-translational processing. J Biol Chem 261:11880-11889

5. Orskov C, Holst JJ, Knuhtsen S, Baldissera FG, Poulsen SS, Nielsen OV (1986) Glucagon-like peptides GLP-1 and GLP-2, predicted products of the glucagon gene, are secreted separately from pig small intestine but not pancreas. Endocrinology 119:1467-1475

6. Sinclair EM, Drucker DJ (2005) Proglucagon-derived peptides: mechanisms of action and therapeutic potential. Physiology (Bethesda) 20: 357-365

7. Habegger K, Heppner K, Geary N, Bartness T, DiMarchi R, Tschop M (2010) The metabolic actions of glucagon revisited. Nat Rev Endocrinol 6:689-697

8. Fehmann HC, Goke R, Goke B (1992) Glucagon-like peptide1(7-37)/(7-36)amide is a new incretin. Mol Cell Endocrinol 85:C39-C44

9. Lam NT, Kieffer TJ (2002) The multifaceted potential of glucagonlike peptide-1 as a therapeutic agent. Minerva Endocrinol 27:79-93

10. Madsbad S (2009) Exenatide and liraglutide: different approaches to develop GLP-1 receptor agonists (incretin mimetics) - preclinical and clinical results. Best Pract Res Clin Endocrinol Metab 23:463477

11. Maida A, Lovshi JA, Baggio LL, Drucker DJ (2008) The glucagonlike peptide 1 receptor agonist oxyntomodulin enhances beta-cell function but does not inhibit gastric emptying in mice. Endocrinology 149:5670-5678

12. Kosinski JR, Hubert J, Carrington P et al (2012) The glucagon receptor is involved in mediating the body weight-lowering effects of oxyntomodulin. Obesity 20:1566-1571

13. Kerr B, Flatt P, Gault V (2010) (D-Ser $\left.{ }^{2}\right)$ Oxm[mPEG-PAL]: a novel chemically modified analogue of oxyntomodulin with antihyperglycaemic, insulinotropic and anorexigenic actions. Biochem Pharmacol 80:1727-1735

14. Santoprete A, Capito E, Carrington P et al (2011) DPP-IV-resistant, long-acting oxyntomodulin derivatives. J Pept Sci 17:270-280 
15. Day J, Gelfanov V, Smiley D et al (2012) Optimisation of coagonism at GLP-1 and glucagon receptors to safely maximise weight reduction in DIO-rodents. BioPolymers (Pept Sci) 98: 443-450

16. McClenaghan NH, Barnett CR, Ah-Sing E et al (1996) Characterization of novel glucose-responsive insulin-secreting cell line, BRIN-BD11, produced by electrofusion. Diabetes 45:11321140

17. Flatt PR, Bailey CJ (1981) Abnormal plasma glucose and insulin responses in heterozygous lean $(\mathrm{ob} /+)$ mice. Diabetologia 20:573577

18. Gault VA, Bhat VK, Irwin N, Flatt PR (2013) A novel glucagon-like peptide-1 (GLP-1)/glucagon hybrid peptide with triple-acting agonist activity at glucose-dependent insulinotropic polypeptide, GLP-1, and glucagon receptors and therapeutic potential in high fat-fed mice. J Biol Chem 288:35581-35591

19. Gault VA, Porter DW, Irwin N, Flatt PR (2011) Comparison of subchronic metabolic effects of stable forms of naturally occurring GIP(1-30) and GIP(1-42) in high-fat fed mice. J Endocrinol 208: 265-271

20. Irwin N, Montgomery IA, Moffett RC, Flatt PR (2013) Chemical cholecystokinin receptor activation protects against obesity-diabetes in high fat fed mice and has sustainable beneficial effects in genetic ob/ob mice. Biochem Pharmacol 85:81-91

21. Ryan GJ, Foster KT, Jobe LJ (2011) Review of the therapeutic uses of liraglutide. Clin Ther 33:793-811

22. Akkati S, Sam KG, Tungha G (2011) Emergence of promising therapies in diabetes mellitus. J Clin Pharmacol 51:796-804

23. Irwin N, Flatt PR (2013) Enteroendocrine hormone mimetics for the treatment of obesity and diabetes. Curr Opin Pharmacol 13:989-995

24. Sadry SA, Drucker DJ (2013) Emerging combinatorial hormone therapies for the treatment of obesity and T2DM. Nat Rev Endocrinol 9:425-433

25. O'Harte FP, Franklin ZJ, Rafferty EP, Irwin N (2013) Characterisation of structurally modified analogues of glucagon as potential glucagon receptor antagonists. Mol Cell Endocrinol 381: 26-34

26. Irwin N, Franklin ZJ, O'Harte FP (2013) desHis(1)Glu(9)glucagon-[mPEG] and desHis(1)Glu(9)(Lys(30)PAL)-glucagon: long-acting peptide-based PEGylated and acylated glucagon receptor antagonists with potential antidiabetic activity. Eur J Pharmacol 709:43-51

27. Pocai A, Carrington P, Adams J et al (2009) GLP-1/GCGR dual agonism reverses obesity in mice. Diabetes 58:2258-2266

28. Unson CG, Macdonald D, Merrifield RB (1993) The role of histidine-1 in glucagon action. Arch Biochem Biophys 300:747-750
29. Parlevliet ET, Heijboer AC, Schröder-van der Elst JP et al (2008) Oxyntomodulin ameliorates glucose intolerance in mice fed a highfat diet. Am J Physiol Endocrinol Metab 294:E142-E147

30. Simonsen L, Holst JJ, Madsen K, Deacon CF (2013) The C-terminal extension of exendin-4 provides additional metabolic stability when added to GLP-1, while there is minimal effect of truncating exendin-4 in anaesthetized pigs. Regul Pept 181:17-21

31. Tatarkiewicz K, Hargrove DM, Jodka CM et al (2014) A novel longacting glucose-dependent insulinotropic peptide analogue: enhanced efficacy in normal and diabetic rodents. Diabetes Obes Metab $16: 75-85$

32. Gault VA, Irwin N, Harriott P, Flatt PR, O'Harte FP (2003) DPP IV resistance and insulin releasing activity of a novel di-substituted analogue of glucose-dependent insulinotropic polypeptide, (Ser2-Asp13)GIP. Cell Biol Int 27:41-46

33. Druce MR, Minnion JS, Field BC et al (2009) Investigation of structure-activity relationships of oxyntomodulin (Oxm) using Oxm analogs. Endocrinology 150:1712-1722

34. Underwood CR, Parthier C, Reedtz-Runge S (2010) Structural basis for ligand recognition of incretin receptors. Vitam Horm 84:251-278

35. Claus TH, Pan CQ, Buxton JM et al (2007) Dual-acting peptide with prolonged glucagon-like peptide-1 receptor agonist and glucagon receptor antagonist activity for the treatment of type 2 diabetes. J Endocrinol 192:371-380

36. Pan CQ, Buxton JM, Yung SL et al (2006) Design of a long acting peptide functioning as both a glucagon-like peptide-1 receptor agonist and a glucagon receptor antagonist. J Biol Chem 281:1250612515

37. Brubaker PL, Drucker DJ (2004) Minireview: glucagon-like peptides regulate cell proliferation and apoptosis in the pancreas, gut, and central nervous system. Endocrinology 145:2653-2659

38. Nolan CJ, Damm P, Prentki M (2011) Type 2 diabetes across generations: from pathophysiology to prevention and management. Lancet 378:169-181

39. Irwin N, McClean PL, Cassidy RS et al (2007) Comparison of the anti-diabetic effects of GIP- and GLP-1-receptor activation in obese diabetic (ob/ob) mice: studies with DPP IV resistant N-AcGIP and exendin(1-39)amide. Diabetes Metab Res Rev 23:572-579

40. Irwin N, Hunter K, Montgomery IA, Flatt PR (2013) Comparison of independent and combined metabolic effects of chronic treatment with (pGlu-Gln)-CCK-8 and long-acting GLP-1 and GIP mimetics in high fat-fed mice. Diabetes Obes Metab 15:650-659

41. Irwin N, Hunter K, Frizzell N, Flatt PR (2009) Antidiabetic effects of sub-chronic activation of the GIP receptor alone and in combination with background exendin-4 therapy in high fat fed mice. Regul Pept 153:70-76 